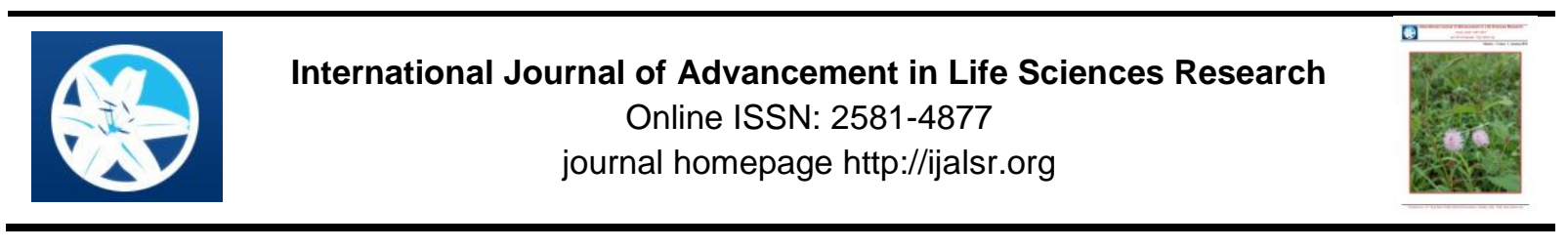

Original Article

\title{
Molecular Mechanism Prediction of Protein from Moringa oleifera Leaves using Computational Approach
}

\author{
Ariana Listuhayu Wahyuni, Farahdita Devi Masyitoh \\ Medical Laboratory Technology Department, Maharani Health Collage of Malang, J. Akordion Selatan 8B \\ Malang, Indonesia. \\ Correspondence E- mail: arianalw@stikesmaharani.ac.id; farahdita@stikesmaharani.ac.id
}

\begin{abstract}
Moringa oleifera (kelor) is one of Indonesia's natural wealth that potentially be an alternative therapy of health problems. Various studies have proved that its can act as a barrier to the development of cancer cells and overcome metabolic syndrome problems. Moringa oleifera is also reported rich with beneficial proteins, so it can be used as alternative food. This study aims to separate mixture proteins (proteome) of Moringa oleifera leaves varieties Madura and Nusa Tenggara Barat (NTB). The study design was exploratory and used SDS-PAGE, then profiled the predicted protein in SDS-PAGE gel. The sampling technique was accidental sampling, data analysis was descriptive and used online software analysis of protein (world-2page.expassy.org/). The results of SDS-PAGE compared with proteins marker standard, it showed there was consistently protein ribbon that appeared in both varieties, in range of $36 \mathrm{kDa}$ molecular weight, then data compared with Arabidopsis thaliana for protein leaves database. The result showed that there is one consistent protein band on Moringa oleifera NTB, in the range $55 \mathrm{kDa}$. This protein also predicted has a molecular function as calcium binding protein. Moringa oleifera Madura, have two predicted protein that expressed in range $36 \mathrm{Kda}$. The first protein was pyruvate dehidrogenase $\mathrm{E} 1$ component sub unit beta with predicted molecular weight $35,7 \mathrm{kDa}$, that important in composing Acetyl CoA, as an oxydoreductase, an enzyme that facititates the acetyl transfer mechanism and the other protein was probable araginase component which have predicted molecular weight $35,5 \mathrm{kDa}$, and have a molecular function as hydrolase on nitrogen metabolism and urea cycle.
\end{abstract}

Keywords: Moringa oleifera, Predicted Protein, In Sillico study

\section{Introduction}

Protein is one of the functional macromolecules, as a result of DNA synthesis. It plays an important role in various cellular processes and its owe a dynamic nature, which means it can undergo changes due to both external and internal stimuli. Changes in protein may occur due to genetic errors (mutations of DNA coding), post transcriptional regulation, or disturbance and alterations to DNA-transcribed mRNA or to post translational modification (PTM) (modification after the protein has been synthesized).

Certain plants or part of the plants also contain proteins that are important for their metabolism. Protein $\mathrm{S}$ within plants are often similar with those that produce in animal cells. They are also found as a component of enzymes and hormones, membrane and cytoplasmic protein composers. 
Indonesia is a diversity rich country and having a lot of varies types of plants. It is necessary to explore its interests in various fields, related to local wisdom of the nation that using the plants for many purposes. Moringa oleifera (kelor in Indonesia terminology) is one of the plant that has recently gained the attention of many researchers. Kelor or Moringa $s p$ is a common plant, grown in Asia, the Arabian Peninsula, and Africa. Kelor is known for having various functions from the field of food to drugs. The nutritious ingredients in Moringa sp. are vitamins (carotenoids) and some essential amino acids. They are used to overcome various health problems, from mild to severe diseases such as cancer. Several studies that have been performed today have shown that Moringa extract has potential in the treatment of chronic hyperglycemia and dyslipidemia (Mbikay, 2012), increases the potency of pancreatic cancer cytotoxicity in the chemotherapy process (Berkovich et al., 2013). It also has anticancer and anti-oxidant potential (Charoensin, 2014). Chuang et al. (2007) also mentioned that seed extract and leaf of Moringa oleifera Lam is an anti-fungal agent against Richophyton rubrum, Trichophyton mentagrophytes, Epidermophyton xoccosum, and Microsporum canis.

Since the Indonesian ancient Moringa oleifera are used as food and drugs component. This plant related to some rituals that exist in Indonesia people's life. Madura and NTB are some of the areas known as the Moringa oleifera habitat in Indonesia. Adawiyah (2013) states that the use of Moringa oleifera is one of indigenous knowledge that still maintained by Gili Ketapang Probolinggo people, who have ancestors from Madura. Bahriyah et al. (2015) also stated that the Moringa leaf is popularly used by Somber s, Sampang and Madura villagers. It has potential as food such as vegetables and livestock feed. $M$. oleifera also has some traditional medicine functions such as, hot sore, sawan, cough, stomach pain treatment, stamina enhancer, convulsions, internal heat, headache, cholesterol, malnutrition, gout, diabetes, mumps and thypii fever. It also has a role in a custom ritual includes nadzar, relievers, corporal baths, birthing process, possession, and pagut. In addition, it also uses as a natural fence for home barrier, and economic value for agate stone (jewelry).

Proteome Analysis (proteomics analysis) is a study of the collection of proteins produced by a living system, at a given time and background. The result is a protein profile that can be used for a variety of purposes, for example as a basis for the discovery of new biomarkers or the basis of detection of abnormalities in cell disorders. One technique that commonly used in proteome analysis is sodium dodecyl sulfate polyacrylamide gel electrophoresis (SDS-PAGE). SDS-PAGE is used for separating proteins in a biological fluid based on their movement in an electric current. This movement is influenced by the length of the expressed polypeptide chain as its molecular weight. This technique is commonly used, either singly or combined with several other techniques such as isoelectric focusing and blue native pages.

Based on the description above, we want do the separation of $M$. oleifera leaves using SDS-PAGE method in order to gain protein profile. The results of this study are a preeliminary stage in mapping a variety of protein taken from $M$. oleifera leaves, collected from Madura and NTB, and possibly various molecular mechanisms that are suspected to be influenced by these proteins in living cells. This information can be an empirical basis for the discovery of new therapies in various diseases as well as the benefits of food from M. oleifera leaves.

Proteome is defined as the expression of protein at the stages of dynamic conditions, meaning that it can undergo changes due to both external and internal stimuli (Abbot, 1999 in Fey and Larsen, 2001). This approach is closer to the conditions occurring in living systems. Proteome analysis also defined as a direct measurement of the existence and the relative amount of a proteome (Wilkins et al. 1995 in Chandramouli and Qian, 2009). Pedersen (2002) mentioned that proteome analysis is one of the approaches that involves in separation, identification and quantification of proteome from biological samples with a variety of purposes, such as exposing certain cell functions. It's application can help identify 
the types of cancer cells as well as the development of drug use, and monitor the changes that occur due to environmental factors.

This proteome analysis can be used to identify different proteome and gene expression on each cell or tissue (Choe et al., 2004). The resulting analysis can be used to compare and identify the occurrence of proteome changes in cells or organisms, both qualitatively and quantitatively to compare some of the conditions to be known, for example in healthy tissue or under certain diseases (Uto et al., 2010). Proteome analysis can also be used to identify proteome proteins in a complex biological system such as serum, plasma, and urine, although initially only used for analysis using simple prokaryote and eukaryote cell subjects (Zhou et al., 2005).

The quality and quantity of a particular proteome can be used as a biological marker of an event or state to be known or researched in an experiment (biomarker). Biomarkers are defined as an indicator of the change in the process of signaling an event in a biological system or sample, as well as cellular, biochemical, and molecular changes measured in a biological medium such as tissues, cells and biofluids (Benford et al. 2000). SDS-polyacrylamide gel electrophoresis (SDS-PAGE) is the process of separating proteins in a mixture based on their molecular weight. The heating process and the denaturation and reduction conditions, made the protein becomes unfolded and coated by SDS detergent molecules, causing negatively charged peptide chains. The loading process of the gel matrix as well as the electric field will cause the negatively charged peptides to migrate toward the positively charged electrodes that are separated by the molecular weight of different protein components (Roy and Kumar, 2012).

Moringa oleifera is known as kelor at Indonesia. It is a small-sized tree, the shape of a leaf is almost similar to a peanut plant. The tree reaches up to $8 \mathrm{~m}$ high and stem circumference $60 \mathrm{~cm}$ dbh. The trunk is bent, often branching off near the base. Smooth bark, dark gray, yellowish sap. Twigs and shoots short and hairy. The flower crown is wide, open, umbrella-shaped, and is generally trunked and deeply rooted.

The leaves are dark green at the top and are paler on the surface. It varies in size and shape, but is generally rounded-elliptic, measuring about $2.5 \mathrm{~cm}$ in length. Flowers generated throughout the year and located in the area of loose axillary panicles with a length of about $15 \mathrm{~cm}$. The flower stalk is separate (individual) with a length of $12 \mathrm{~mm}$ and is very slender, has 5 green colored with $12 \mathrm{~mm}$ in length, 5 petala is white, unequal, slightly longer than the sepala, has 5 stamen with anther and 5 without anther; sweet smelling flowers. The fruit is large with a length of about $90 \mathrm{~cm}$ and a diameter of $12 \mathrm{~mm}$. It has black and oily fruit seeds. Grows at an altitude of 0 $1000 \mathrm{~m}$, temperatures average 12.6 to $40^{\circ} \mathrm{C}$, average rainfall of at least $500 \mathrm{~mm}$, and adaptive in almost all soil types but prefer slightly acid soils (www.agroforestry.org).

Moringa oleifera has various benefits. For example, it can be used for disease prevention, scouring oil, natural fertilizer, erosion control plants, water purification, cosmetics making materials, textile paints, insecticides, fungicides, blue dyes, yarn making materials, windbreaks, foodstuffs, animal feed ingredients, and biogas (www.miracletrees.org). Busani et al. (2011) study has proven that Moringa oleifera leaf acetone extract at $5 \mathrm{mg} / \mathrm{ml}$ concentration showed antibacterial activity to Escherichia coli, Enterobacter cloace, Proteus vulgaris, Staphylococcus aureus and Micrococcus christinae. Moringa oleifera also has potential as a medicinal substance that has high nutritional content, many containing proteins, vitamins, $\beta$-carotene, amino acids and various phenolic compounds (Anwar et al.., 2007; Razis et al.., 2014). Lutfiyah (2012) in his research stated that kelor is one type of plant that is very easy to grow and not easy to die, despite growing in a poor environment of nutrients, including in West Nusa Tenggara. In addition, this plant is also widely used as food in the form of processed vegetables by the people of NTB, while Adawiyah (2013) states that the use of Moringa oleifera including one of indigenous knowledge (traditional local knowledge) is still maintained by the people of 
Gili Ketapang Probolinggo, which has an ancestor from Madura. Natural conditions formed from coral reefs and around the ocean, causing the climate dry and barren, so the use of Moringa oleifera which is one of 22 species of woody plants commonly used by the people of Gili Ketapang is one alternative to survive in life. Some of its uses include foodstuffs, boats and ships, fish houses, medicines, firewood, building materials, fodder and carving. Research conducted by Bahriyah et al. (2015) also stated that the leaves of Moringa are quite popularly used by the people of the village of Somber Sampang and Madura. They used the plant as food such as vegetables and livestock feed. Traditional medicine includes hot sore, convulsions, cough, stomach pain, stamina enhancer, internal heat, headache, cholesterol, malnutrition, gout, diabetes, mumps and tipes. As a custom ritual includes nadzar, relievers, corporal baths, birthing process, possession, and pagut. In addition, fencing plants for home barriers, and economic value for agate stones (jewelry). The highest utilization of kelor is for food.

\section{Method}

This study was carried out through experimental approach and descriptive analysis. Moringa oleifera leaves were collected from Madura and NTB to make a profile. The study was held from July until August 2017 at Laboratorium Biologi Molekuler Fakultas MIPA Brawijaya University Malang. Four main steps were involved in this study. First, Moringa oleifera leaves were collected from Madura and NTB. Second, the processing made of Moringa oleifera (MOE) using RIPA buffer method. Third, protein were separated using SDS-PAGE. Finally, predicting the protein in the MOE using Swiss model, and predict the molecular mechanism using Panther data base.

\section{Result}

Protein profile of both extract was scanned on the SDS-PAGE gel (Fig 1 and 2). The predicted proteins were blotted on the gel and appeared as a bluish band. It was based on the coloring reagent Coomassie Blue Staining $(C B B)$.The sample band was compared with marker of universal molecular weight. Then, the predicted of molecular weight of the proteins were observed. From the experiment, we found that one consistent band was appeared in the NTB extract on all sample conditions. The band size was $55 \mathrm{kDa}$, while Madura extract, has a band size of $36 \mathrm{kDa}$. The slight difference between the shoot ("young leaves") and the real leaves was the band density, on the shoot (lane 5-8), the band were thicker compared to the real leaves (lane $1-4)$.
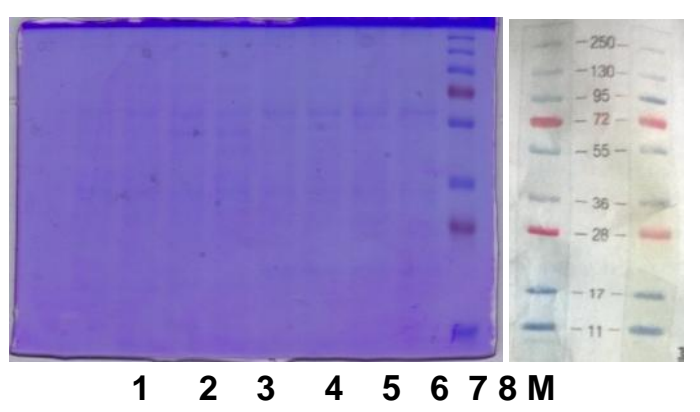

Fig.1 The Protein Profile of Mataram Moringa oleifera

Line 1-4: Daun tua

Line 5-8 : Daun muda

M : Marker

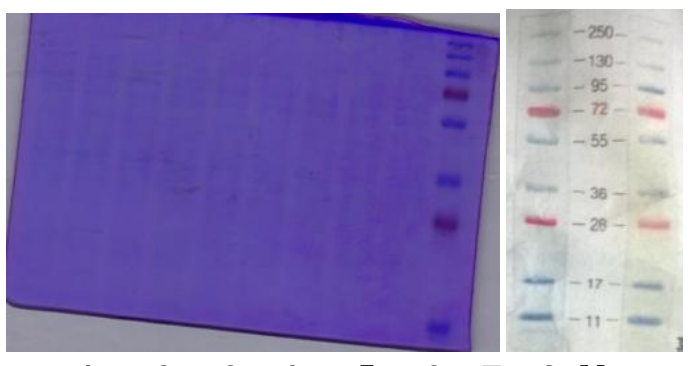

$\begin{array}{lllllllll}1 & 2 & 3 & 4 & 5 & 6 & 7 & 8 & M\end{array}$

Fig.2 The Protein Profile of Madura Moringa oleifera

Line 1-4: Daun tua

Line 5-8 : Daun muda

M : Marker

Fig.2 shows that there was a consistent protein expression from Madura Moringa oleifera leaves. The proteins were expressed as blue band in Lane 1 to 8 with $36 \mathrm{kDa}$ molecular weight. The protein bands were uniform, which means there were no difference in terms of density between the shoot and real leaves extract.

We also make a prediction of the protein and the function using websitehttp://world2dpage.expasy.org/swiss-2dpage and http://pantherdb.org, and the result were shown on the Table 2. 
Table 2.Predicted protein based on Swiss Protein data base

\begin{tabular}{|c|c|c|c|c|}
\hline No & Extract & Protein Prediction & $\begin{array}{c}\text { BM } \\
(\mathrm{kDa})\end{array}$ & Location \\
\hline \multirow{2}{*}{1} & \multirow{2}{*}{ Madura } & $\begin{array}{c}\text { Pyruvate dehidrogenase E1 } \\
\text { component sub unit beta }\end{array}$ & 35.7 & Mitochondria \\
\cline { 3 - 5 } & Probable Araginase & 35.5 & Mitochondria \\
\hline 2 & NTB & Calreticulin & 55.0 & $\begin{array}{c}\text { Lumen of the Endoplasmic } \\
\text { Reticulum }\end{array}$ \\
\hline
\end{tabular}

The protein accession number was used to access predicted protein from the panther database.

The first Madura predicted protein has molecular weight of $35.7 \mathrm{kDa}$. It was subunit beta from pyruvate dehydrogenase $\mathrm{E} 1$. It located in mitochondria. Complex pyruvate dehydrogenase is an enzyme that will catalyze the pyruvate conversion into acetyl $\mathrm{CoA}$ and $\mathrm{CO}_{2}$. This complex contains of three sub unit: Pyruvate dehydrogenase sub unit $\mathrm{E} 1$ beta (E1), Dihydrolipoamideacetiltransferase (E2), and Lipoamidedehidrogenase (E3). This enzyme needs cofactor, thiamine biphosphate. E1 sub unit has molecular function as oxidoreductase in acetyl transfer. This enzyme also involved in acetyl CoA biosynthesis, glycolysis, and bacterial defence mechanism. This enzyme, mainly expressed in the root and mature and immature roset, on Arabidopsis thaliana. The second protein predicted on Madura extract was part of araginase 2 enzyme, which act as hydrolase and catalyze in the hydrolysis of L-arginine into L-ornithine and urea in the urea cycle. It also has a role in nitrogen metabolism. L-ornithinin urea cycle important as a polyamine precursor and proline. The database also stated that the plant which over-expressing this protein, could decrease the immune system towards fungal.

This enzyme needs $\mathrm{Mn}^{2+}$, as a catalyst. One of the subunit will bond to two $\mathrm{Mn}^{2+}$ ions. This protein involved in some cellular molecular functions such as arginase activity and cobalt binding. This protein also involved in other mechanisms. For example, arginine

\section{References}

Adawiyah, R. (2013). Jenis-jenis tumbuhan Berkayu dan Pemnafaatannya oleh Suku Madura di Pulau Gili Ketapang Probolinggo. metabolism, fungal defense mechanism, ornithinproline, putrescine, tyrosine metabolism and also urea cycle.

On Arabidopsis thaliana the tissue that expressed this protein mainly are: root vessel, root tip, leaves and cotyldon.This protein expression was induced byMetil jasmonate and pathogen $B$. Cinerea infection.

Fivety-five $k D a$ of predicted protein from Mataram Moringa oleifera predicted as calreticulin. This protein is a calcium chaperone and has a calcium binding action. It also has a role in oligomeric arrangement and quality control of protein in the reticulum endoplasmic which involves in calreticulin orcalnexin cycle. This protein will bind transiently with almost all monoglucosylated glycoprotein that synthesize inside the endoplasmic reticulum. Generally, this protein will bind to calcium, carbohydrate, and protein that haven't through folding. This protein has role in some biological process such as protein folding, cadmium ion response, oxidative stress and salt stress response.

In this study, A. thaliana database was used to compare with our Moringa $s p$ profile results . $A$ thaliana is a common plant that used in many molecular researches. It has some advantages such as propagate easily, short life time, and complete database on website.

This study has shown that there were some proteins expressed from Moringa oleifera, but this finding was still on pre-eliminary stage. Therefore, we suggested that further studies should be carried out on 'kelor'.

Skripsi. Jurusan Biologi, FMIPA, Universitas Jember. 
Anwar, F., Latif, S. , Ashraf, M., \& Gilani, A. H. (2007). Moringa oleifera: A Food Plant with Multiple Medicinal Uses. Phytother. Res. 21, 17-25.

Bahriyah, I., Hayati, A. \& Zayadi, H. (2014). Studi Etnobotani Tanaman Kelor (Moringa oleifera ) di Desa Somber Kecamatan Tambelangan Kabupaten Sampang Madura, Jurusan Biologi, FMIPA, Universitas Islam Malang, Indonesia.

Benford, D. J., Hanley, A. B., Bottril, K., Oehlschlager, S., Balls, M., Branca, F., Castegnaro, J. J., Descotes, J., Hemminiki, K., Lindsay, D., and Schilter, B. (2000). Biomarkers as Predictive Tools in Toxicity Testing, The Report and Recommendations of ECVAM Workshop 40, ATLA 28, 119-131.

Berkovich, L., Earon, G., Ron, I., Rimmon, A., Vexler, A. \& Lev-Ari, S. (2013). Moringa Oleifera aqueous leaf extract down-regulates nuclear factor-kappa $B$ and increases cytotoxic effect of chemotherapy in pancreatic cancer cells, BMC Complementary and Alternative Medicine. 13, 212.

Busani, M., Masika, P. J., Mucheenje, V. (2012). Antimicrobial activities of Moringa oleifera Lam leaf extracts, African Journal of Biotechnology. 11(11), 2797-2802.

Chandramouli, K., \& Qian, P.-Y. (2009). Proteomics: Challenges, Techniques and Possibilities to Overcome Biological Sample Complexity. Human Genomics and Proteomics: $\quad H G P, 2009, \quad 239204$. http://doi.org/10.4061/2009/239204.

Charoensin, S. (2014). Antioxidant and anticancer activities of Moringa oleifera leaves, Journal of Medicinal Plant Research, 8(7), 318-325

Choe, C., Park J.W., Kim E. S., Lee S .G, Park S.Y, Lee J.S., Cho M.J, Kang K.R., Han J H., \& Kang D.W. (2010). Proteomic Analysis of Differentially Expressed Proteins in Bovine Endometrium with Endometritis, Korean $J$ Physiol Pharmacol, 14(4), 205-212

Chuang, Ping-Hsien, Lee, Chi-Wei, Chou, JiaYing, Murugan, M., Shieh, Bor-Jinn, Chen, Hueih-Min. (2007). Anti-fungal activity of crude extracts and essential oil of Moringa oleifera Lam. Bioresource Technology 98, 232-236.
Fey, S. J., and Larsen, P.M., (2001). 2D or not 2D, Current Opinion in Chemical Biology, Elsevier Science Ltd. 5, 26-33.

http://world-2dpage.expasy.org (online analysis database)

http://www.pantherdb.org (online analysis database)

http://www.worldagroforestry.org/treedb/AFTP DFS/Moringa oleifera.PDF

Luthfiyah., F., 2012, Potensi Gizi Daun Kelor (Moringa oleifera) Nusa Tenggara Barat, Media Bina IImiah. Volume 6, No. 2.

Mbikay, M. (2012). Therapeutic Potemtial of Moringa oleiera leaves in chronic hyperglycemia and dyslipidemia : a review, Frontiers in Pharmacology, 3(24), doi: 10.3389/fphar.2012.00024.

Pedersen, L. (2002). Analysis of Two Dimensional Electrophoresis Gel Images, Informatics and Mathematics Modelling, Thesis, Technical University of Denmark.

Razis, A.F.A., Ibrahim, Md., andKntayya, S.B. (2014). Health benefits of Moringa oleifera, Asian Pacific Journal of Cancer Prevention.15(20), 8571-6.

Roy, S. \& Kumar, V.( 2014). A Practical Approach on SDS PAGE for Separationof Protein, International Journal of Science 3(8), 955-960.

Roy, V. K., Kumar, N S., \& Gurusubramanian, G. (2012). Proteins - structure, properties and their separation by SDS-polyacrylamide gel electrophoresis, Science Vision. 12(4), 170181.

Uto, H., Kanmura, S., Takami, Y., \& Tsubouchi, H. (2010). Clinical proteomics for liver disease: a promising approach for discovery of novel biomarkers. Proteome Science. 8, 70. http://doi.org/10.1186/14775956-8-70

Zhou, M., Conrads, T. P., \& Veenstra, T. D. (2005). Technique Review : Proteomics Approaches to Biomarker Detection, J. Briefing in Functional Genomics and Proteomics. 4 (1), $69-75$. 